\title{
Author Correction: LSD1 inhibition sustains T cell invigoration with a durable response to PD-1 blockade
}

Yi Liu, Brian Debo, Mingfeng Li (1), Zhennan Shi, Wanqiang Sheng (10) \& Yang Shi (1)

Correction to: Nature Communications https://doi.org/10.1038/s41467-021-27179-7, published online 24 November 2021.

The original version of this article contained errors in Fig. 1c, h, 3b and Supplementary Fig. 8c.

In Fig. $1 \mathrm{c}, \mathrm{h}$ and Supplementary Fig. $8 \mathrm{c}, p$ values were incorrectly presented as $0.0016,0.93,0.0025$, respectively. The correct $p$ values are 0.0017 (Fig. 1c), 0.92 (Fig. 1h), 0.0013 (Supplementary Fig. 8c).

In Fig. 3b, the frequency of CD8 $+\mathrm{T}$ cells in the FTY720 group, day 20 flow cytometry panel was incorrectly presented as 0.0064 . The correct value is 0.064 .

The original Source data file contains the correct values.

These errors have been corrected in the PDF and HTML versions of the article and in the Supplementary Information file.

Published online: 05 January 2022

\section{Additional information}

Supplementary information The online version contains supplementary material available at https://doi.org/10.1038/s41467-021-27814-3.

\footnotetext{
(c) (i) Open Access This article is licensed under a Creative Commons Attribution 4.0 International License, which permits use, sharing, adaptation, distribution and reproduction in any medium or format, as long as you give appropriate credit to the original author(s) and the source, provide a link to the Creative Commons license, and indicate if changes were made. The images or other third party material in this article are included in the article's Creative Commons license, unless indicated otherwise in a credit line to the material. If material is not included in the article's Creative Commons license and your intended use is not permitted by statutory regulation or exceeds the permitted use, you will need to obtain permission directly from the copyright holder. To view a copy of this license, visit http://creativecommons.org/licenses/by/4.0/.
}

(c) The Author(s) 2022 